\title{
Ryhmäosaaminen lukiossa on kaikkien asia
}

\section{Kati Timonen}

\begin{abstract}
Viittausohje:
Timonen, K. (2021). Ryhmäosaaminen lukiossa on kaikkien asia. Prologi - Viestinnän ja vuorovaikutuksen tieteellinen aikakauslehti, 17(1), 42-47. https://doi.org/10.33352/prlg.103262

To cite this article:

Timonen, K. (2021). Ryhmäosaaminen lukiossa on kaikkien asia [Group communication competence in upper secondary school belongs to everyone]. Prologi - Journal of Communication and Social Interaction, 17(1), 42-47. https://doi.org/10.33352/prlg.103262
\end{abstract}

Prologi

- Viestinnän ja vuorovaikutuksen tieteellinen aikakauslehti journal.fi/prologi/

ruotsiksi: Prologi - Tidskrift för Kommunikation och Social Interaktion englanniksi: Prologi - Journal of Communication and Social Interaction Julkaisija: Prologos ry.

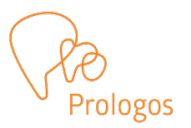

Avoin julkaisu / Open Access ISSN 2342-3684 / verkko ISSN 1795-7613 / painettu versio 


\title{
Lectio Praecursoria
}

\section{Ryhmäosaaminen lukiossa on kaikkien asia}

\author{
Kati Timonen \\ FT, Lukion äidinkielen ja kirjallisuuden lehtori \\ kati.timonen@lyk.fi
}

vastaanotettu 13.3. / hyäksytty 16.3. / julkaistu 5.5.2021

ASIASANAT: lukio, opetusviestintä, oppikirja, puheviestintä, ryhmäosaaminen

Lectio praecursoria puheviestinnän väitöskirjaksi (monografia) tarkoitetun tutkimuksen $\mathbf{R y h m a ̈ o s a a - ~}$ minen lukiossa. Lukiolaisten ryhmäosaamisen kehittyminen ja kehittäminen tarkastustilaisuudessa Jyväskylän yliopistossa 28.11.2020. Vastaväittäjänä toimi koulutus- ja kehittämisjohtaja, dosentti, FT Anne Laajalahti (Infor Oy/ Vaasan yliopisto) ja kustoksena lehtori, FT Tarja Valkonen (Jyväskylän yliopisto).

Väitöskirja on luettavissa verkossa osoitteessa http://urn.fi/URN:ISBN:978-951-39-8393-2

Opetus, oppiminen ja koulu ylipäänsä muodostavat yhden merkittävän perustan suomalaiselle yhteiskunnalle. Siksikin opetuksesta ja oppimisesta puhutaan paljon, ja ne herättävät laajasti erilaisia ajatuksia ja mielipiteitä, paikoin kiivastakin sananvaihtoa. Suomessa uskotaan vankasti edelleen koulutuksen voimaan, ja erinomaista koululaitostamme arvostetaan niin meillä kuin maailmallakin. Opetuksen ke- hittäminen on, tai ainakin sen tulisi olla, jatkuvaa, tietoista ja yhteistyössä tapahtuvaa, myös tutkimukseen nojautuvaa. Koulun voi väittää olevan oikeastaan jatkuvassa liikkeessä. Koulu ja opetus ovat vuorovaikutuksessa ympäröivän yhteiskunnan kanssa, ja näin koulu reagoi sille asettuviin tavoitteisiin ja muutostarpeisiin. Yksi keskeinen tie pitää yllä ajankohtaista opetusta on opetussuunnitelmauudistukset. 
Perusopetuksessa otettiin käyttöön uudistettu opetussuunnitelma portaittain 2016, ja lukion valtakunnallinen opetussuunnitelmauudistus astuu voimaan elokuussa 2021, jolloin myös oppivelvollisuusikä laajenee 18 ikävuoteen. Se tarkoittaa käytännössä sitä, että pakollisen perusopetuksen lisäksi jokaisen tulee suorittaa joko lukio- tai ammattikoulutus. Uudistukset ovat isoja ja niiden vaikutukset kauaskantoisia. Tämän vuoksi on tärkeää paitsi tehdä perusteltuja muutoksia ja uudistuksia myös pyrkiä varmistamaan, että ne toteutuvat ja näkyvät käytännön opetusarjessa.

Tässä tutkimuksessa tarkasteltiin ryhmäosaamisen ilmiötä lukiolaisten näkökulmasta, suomalaisessa lukiokontekstissa. Ryhmäosaaminen on osa vuorovaikutusosaamista, jonka on osoitettu monin tutkimuksin olevan ydinosaamista niin nykyisessä työelämässä kuin yleisemminkin sosiaalisessa elämässä ja yhteisöissä. Ryhmäosaamisella tarkoitetaan siis sellaista vuorovaikutusosaamista, jota edellytetään ja sovelletaan erilaisissa ryhmissä ja tiimeissä. Ryhmäosaaminen muodostuu erilaisista ryhmätaidoista, ryhmiin liittyvästä tiedosta ja viestijän motivaatiosta osallistua ryhmän vuorovaikutukseen ja asenteesta ylipäänsä vuorovaikutustilannetta kohtaan. Siihen katsotaan kuuluvaksi niin ikään metakognitiiviset taidot, joilla säädellään ja hallinnoidaan omaa vuorovaikutuskäyttäytymistä.

Ryhmäosaaminen on kontekstisidonnaista. Erilaiset vuorovaikutustilanteet painottavat erilaista ryhmäosaamista, ja eri tilanteissa ryhmäosaamisen kaksi kriteeriä, tehokkuus ja tarkoituksenmukaisuus, määrittyvät tilanteen ja osallistujien ehdoilla. Ryhmäosaamisen voi sanoa olevan muuttuvaa, mukautuvaa ja kehitettävissä olevaa. Se on ihmisiän mittainen prosessi, eikä formaali tai informaalikaan opiskelu lukiossa tietenkään tyhjentävästi tai kaiken kattavasti vastaa lukiolaisen ryhmäosaamisen kehitystarpeeseen. Lukio voi kuitenkin tehdä oman osansa, mitä ei ole syytä väheksyä.

On huomioarvoista, että ryhmäosaaminen on olennainen osa lukiolaisen opiskeluarkea, jatko-opintoja ja työelämäosaamista. Tutkimusten perusteella tiedetään, että ryhmä- ja tiimityöskentely koetaan usein vaativaksi. Siksi lukiolaisten ryhmäosaamiseen on hyödyllistä kiinnittää huomiota, tehdä sen merkitys eri tavoin näkyväksi.

\section{Tutkimuksen lähtökohdat}

Väitöskirjatutkimukseni lähtökohtana oli halu ymmärtää käytännössä ryhmien vuorovaikutusta, ja tutkimuksen päätavoitteena oli kuvata ja ymmärtää ryhmäosaamisen ilmiötä nimenomaan lukiolaisten lähtökohdista. Aiemman tutkimuksen perusteella lukiolaisten ryhmäosaamisesta tiedetään oikeastaan melko niukasti. Tutkimusta voidaan pitää relevanttina, sillä lukiolaisten ryhmäosaamiseen liittyviä kokemuksia ja käsityksiä ei ole juurikaan tutkittu. Tutkimusta motivoikin se, että ryhmäosaamisen ilmiöstä tarvitaan uutta tietoa, jolla on mahdollista myös tukea ja kehittää lukiolaisten työelämävalmiuksia.

Tutkimuksella haluttiin saavuttaa tietoa, jolla ymmärrys lukiolaisten ryhmäosaamisesta laajenee. Tuotetun tiedon avulla on myös mahdollista kehittää lukiolaisten ryhmäosaamisen ohjaamista ja kehittymistä lukio-opinnoissa sekä tuottaa tarkemmin kohdennettuja oppimateriaaleja tähän tueksi. Koin tärkeäksi myös antaa lukiolaisten ajatuksille mahdollisuuden tulla huomioiduiksi.

Väitöskirjani pyrkii vastaamaan kolmeen tutkimuskysymykseen: Mitä ryhmäosaaminen on 
lukiolaisten mukaan? Mitä se on lukion oppikirjoissa? Lisäksi, miten lukiolaisten arvioiden mukaan ryhmäosaaminen on kehittynyt, miten sitä on kehitetty ja miten sitä voitaisiin kehittää nykyistä paremmin lukio-opintojen aikana?

Tutkimuksen tieteenfilosofiset lähtökohdat kytkeytyvät naturalistiseen tutkimusperinteeseen. Toisin sanoen taustalla vaikuttavan paradigman mukaisesti ajatellaan, että tieto on saatavissa ihmisten kokemuksista ja käsityksistä, ja vastaajat luovat merkityksiä subjektiivisten kokemustensa ja käsitystensä kautta. Tutkimuksessa kiinnostus kohdistuu tutkittavan ilmiön ymmärtämiseen ja kuvaamiseen; tutkimuksen tavoitteena on selittää ennen kaikkea ryhmäosaamisen ilmiötä, ei etsiä tai löytää objektiivista totuutta eli todistaa jotakin oikeaksi tai vääräksi.

Keräsin tutkimusta varten kolme erilaista tutkimusaineistoa siten, että kuhunkin tutkimuskysymykseen haettiin vastausta omasta aineistostaan. Tutkimusaineistoja olivat kirjoitelma-aineisto (vastaajina 136 lukiolaista), verkkokyselyaineisto (vastaajina 204 abiturienttia) ja oppikirja-aineisto, joka sisälsi lukiossa opiskeltavan kolmen oppiaineen painettuja oppikirjoja, yhteensä 25 kappaletta. Oppiaineet olivat äidinkieli ja kirjallisuus, ruotsin kieli (B-oppimäärä) ja englannin kieli (A-oppimäärä).

Kirjoitelma-aineisto ja oppikirja-aineisto analysoitiin aineistolähtöisen sisällönanalyysin keinoin. Verkkokyselyaineisto analysoitiin kvantitatiivisesti. Verkkokyselyssä olevan avoimen kysymyksen vastukset analysoitiin aineistolähtöisen sisällönanalyysin keinoin.

\section{Ryhmäosaaminen painottuu taitoihin}

Tulokset osoittavat, että ryhmäosaaminen on lukiolaisten mukaan taitopainotteista, käytännönläheistä osaamista ja tarvepohjaista. Se sisältää

- yhteistyökykyisyyttä,

- keskustelu- ja kuuntelutaitoa,

- päämäärätietoisuutta,

- luotettavuutta,

- ryhmän jäsenten joustavuutta,

- yhdenvertaisuutta,

- kykyä johtaa ja

- ryhmän jäsenten esiintymistaitoa.

Tulokset antoivat viitteitä siitä, että lukiolaisten käsitysten perusteella välittyvä kuva ryhmäosaamisesta on heidän määritelmänsä eräänlaiselle ihanteelle siitä, millaista osaamista ryhmissä tulisi olla. Kiinnostavaa tuloksissa onkin se, etteivät lukiolaiset kuvanneet ryhmäosaamiseen sisältyvän taitoja, joilla hallitaan konflikteja tai ristiriitatilanteita.

Niin ikään lukiolaiset eivät sisällyttäneet ryhmäosaamisensa määritelmään esimerkiksi kykyä arvioida tai antaa palautetta itselle tai toisille siitä, miten onnistunutta ryhmän vuorovaikutus tai työskentely on. Tämä luo kuvan, että lukiolaiset näkivät ryhmäosaamisen senkaltaisena osaamisena, ettei se ole niinkään kehitettävissä olevaa, jota voisi tietoisesti pyrkiä oppimaan ja kehittämään.

\section{Oppikirjoissa ryhmäosaamisessa kehittymisen näkökulmaa tulisi kasvattaa}

Tämän tutkimuksen tulosten mukaan oppikirjoista välittyvä käsitys ryhmäosaamisesta 
on kuvaileva, normittava ja ohjeistava muttei kovinkaan tarkkarajainen tai yksiselitteinen. Tulosten valossa ei oikeastaan voida puhua ryhmäosaamisesta oppikirjoissa, sillä niissä ei ole käytössä ryhmäosaamisen käsitettä eikä ryhmäosaamista myöskään ole oppikirjoissa määritelty. Sen sijaan oppikirjoissa puhutaan moderneista puheviestintätaidoista, esiintymis- ja ryhmäviestintätaidoista ja keskustelutaidoista. Tätä ei voida kuitenkaan pitää varsinaisesti yllättävänä, sillä viestinnän tieteenalalla rinnakkaiset käsitteet kuten ryhmäviestintätaidot tai keskustelutaidot ovat yleisiä. Sen sijaan voidaan ajatella, että oppikirjateksteissä pelkistetty ja yhdenmukaistettu käsitteistö voisi olla tarpeen lukiolaisia ajatellen.

Oppikirjoissa kuvaillaan ryhmän vuorovaikutusta, erilaisia ryhmän vuorovaikutustilanteita ja niissä edellytettäviä ryhmätaitoja. Niissä luodaan normeja sille, millä tavoin ryhmissä tulee toimia, ja ohjeistetaan jonkin verran konkreettisten neuvojen avulla toimimista ryhmän vuorovaikutustilanteissa. Tulokset osoittavat, että oppikirjat sisältävät runsaasti ryhmissä toteutettavia tehtäviä, ja oppikirjoissa ryhmäosaaminen on ensisijaisesti edellytys opiskelulle. Tulosten perusteella oppikirjat ylläpitävät käsitystä siitä, että ryhmäosaaminen ei ole varsinaisesti kehitettävää tai kehittämisen kohde, oppimisen osa-alue tai sen kohde, vaan se on lähes välttämätön edellytys lukio-opiskelulle.

Vaikka oppikirjoissa on ryhmän vuorovaikutuksen arviointiin ohjeistavia sisältöjä, tulosten perusteella ei voida sanoa, että ryhmäosaaminen olisi jotakin kehitettävissä olevaa osaamista. Oppikirjoissa ei nimittäin ole systemaattisesti koottuja tehtäväkokonaisuuksia, joissa myös ryhmäosaamisen kehittymiselle asetettaisiin tavoitteita ja joissa tehtävän jälkeen arvioitaisiin ja annettaisiin palautetta ryhmäosaamiseen liittyen. Oppikirjoissa ei tulosten perusteella myöskään selitetä, onko toistuvilla ryhmätyöharjoituksilla muitakin tavoitteita kuin jonkin oppiaineeseen liittyvän sisällön oppiminen.

Tiedostava ja tavoitteellinen ryhmäosaamisen kehittäminen ei siis niinkään raamita oppikirjoja, sillä arviointikriteereitä, ohjeita palautteenantoon tai esimerkiksi yksilöityjä tarkkailutehtäviä ei juurikaan ole. Kuitenkin ryhmäosaaminen on arvioitavissa kontekstien kautta. Tämän vuoksi arviointitaitojen kehittäminen olisi tärkeää lukiolaisen ryhmäosaamisen kannalta. Toimiminen ryhmissä voisi näin ollen olla siis huomattavasti tiedostavampaa ja tavoitteellisempaa, kenties jopa innostavampaa, myös muuten kuin oppiainesisältöjen vuoksi. Ryhmäosaamisen kehittämiselle voitaisiin asettaa suoraan tavoitteita ja sitten arvioida sekä ryhmäosaamista että tavoitteiden saavuttamista eri tavoin.

\section{Ryhmäosaamisen koettu kehittyminen ja kehittäminen}

Kolmannella tutkimuskysymyksellä pyrittiin vastaamaan siihen, miten lukiolaiset arvioivat oman ryhmäosaamisensa kehittymistä ja kehittämistä lukio-opintojensa aikana. Tulokset osoittivat, että lukiolaisten mukaan lukio tuki ryhmäosaamisen kehittymistä ennen kaikkea esitelmien pitotaidossa, taidoissa työskennellä erilaisten ryhmälaisten kanssa ja aktiivisessa kuuntelutaidossa. Ryhmäosaaminen ei niinkään nähty kehittyvän taidoissa, joita edellytetään reaaliaikaisessa verkkokeskustelussa tai -neuvottelussa kuten ei myöskään taidossa johtaa ryhmää tai ratkaista ristiriitatilanteita rakentavasti.

Vastaajien arviointien mukaan ryhmäosaamisen kehittymistä tukivat teetetyt ryhmätyöt ja erilaiset projektit, pienryhmäkeskustelut ja 
vaihtuvat ryhmäkokokoonpanot. Vastaajien mukaan niin ikään pienet opetusryhmät edistivät ryhmäosaamisen kehittymistä, mutta oppimispäiväkirjan pito, opettajien luennoiva opetustyyli, isot opetusryhmät ja oma, negatiivinen asenne viestintää kohtaan sen sijaan estivät ryhmäosaamisen kehittymistä.

Tulosten perusteella ryhmäosaamisesta saatavalla palautteella ja arvioinnilla on kaiken kaikkiaan myönteistä merkitystä lukiolaisille. He arvioivat, että erityisen hyödyllistä ryhmäosaamisen kehittymiselle olivat opettajan antama kirjallinen, henkilökohtainen arviointipalaute jokaiselle ryhmän jäsenelle, opettajan suullinen palaute jokaiselle ja yhteiset palautekeskustelut opettajan ja ryhmän jäsenten kanssa keskustelun sujumisesta. Lukiolaisten arviointien mukaan niinkään hyödyllisinä ei pidetty kirjallista, itse laadittua arviointia ryhmän suorituksesta tai kirjallista itsearviointia omista ryhmätaidoista. Myöskään opettajan antama numeroarviointi ryhmälle yhteisesti ei lukiolaisten näkemysten mukaan juurikaan hyödytä ryhmäosaamisen kehittymistä.

Tutkimuksen tulokset antavat viitteitä siitä, että lukiolaiset arvostavat ja pitävät ryhmäosaamista tarpeellisena tulevaisuutensa eli jatko-opintojen ja myöhemmin työelämän näkökulmasta. Vastaajista vähintään puolet arvioi, että tarpeellista ryhmäosaamista ovat aktiivinen kuuntelutaito, taito työskennellä erilaisten ryhmäläisten kanssa, neuvottelutaidot, keskustelutaidot, päätösten tekeminen yhdessä ryhmäläisten kanssa, hyvän ilmapiirin luomisen ja ylläpitämisen taito, ristiriitatilanteiden ratkaiseminen rakentavasti, ryhmän toiminnan vieminen kohtia määriteltyä tavoitetta ja perustelutaidot.

Lukiolaisten arviointien mukaan ryhmäosaamisen kehittyminen mahdollistui eniten äidinkielen ja kirjallisuuden oppitunneilla, ruokail- lessa ja koulun yhteisissä tapahtumissa. Sen sijaan heidän mukaansa vähiten ryhmäosaaminen kehittyi matematiikan, luonnontieteiden sekä historian ja yhteiskuntaopin oppitunneilla. On hyvä kuitenkin huomata, että vaikka äidinkieli ja kirjallisuus voidaan perustellusti nähdä keskeisenä ryhmäosaamiseen liittyvänä opetuksen ja ohjaamisen oppiaineena, se tuskin yksin riittää takaamaan ja varmistamaan lukiolaisen ryhmäosaamisen kehittymistä. Taitojen siirrettävyys ei nimittäin aina välttämättä onnistu. Täten ei voida edellyttää, että ryhmäosaamisen kehittyminen on yksinomaan yhden tai muutamankaan oppiaineen vastuulla, vaan sen tulisi olla yhteinen opetuksen ja eri oppiaineiden kiinnostuksen kohde, kuten opetussuunnitelma tarkasti luettuna edellyttääkin.

Lukiolaisten kokemusten mukaan ryhmäosaamisen kehittymistä voitaisiin tukea nykyistä paremmin. He arvioivat, että ryhmäosaamisen kehittymisen ohjaamista voitaisiin parantaa

- vahvistamalla ryhmäosaamiseen liittyvää tietoa ja taitoa

- hyödyntämällä konkreettisia ryhmäosaamista tukevia harjoituksia

- monipuolistamalla opetusmenetelmiä

- ryhmäosaamiseen kohdentuvan palautteen keinoin

- varmistamalla tasavertaiset mahdollisuudet kehittää omaa ryhmäosaamistaan

- kasvattamalla ryhmäosaamisen painoarvoa ja

- lisäämällä opettajien osaamista ryhmäosaamisen ohjaamisessa.

Kokonaisuutena ajatellen tämän tutkimuksen keskeinen johtopäätös on se, että ryhmäosaamisen asemaa olisi tärkeää tehdä näkyvämmäksi, eritoten kahdella tavalla. Ensinnäkin tulisi korostaa sitä, että ryhmäosaaminen on jotakin opittavissa ja kehitettävissä olevaa. Se ei 
siis ole senkaltaista taitoa tai osaamista, jota eri yksilöillä on muuttumattomasti jossakin määrin tai ollenkaan.

Toisekseen koska ryhmäosaaminen on kehitettävissä olevaa, sille olisi tarkoituksenmukaista asettaa selvästi erilaisia tavoitteita, joita voisivat olla ryhmän vuorovaikutukseen ja ryhmäosaamiseen liittyvä tiedon lisääminen, tavoitteelliset harjoitukset ja ryhmäosaamiseen liittyvän palautteen ja arvioinnin hyödyntäminen kehittymisen tukena. Tämä herättää pohdintoja siitä, onko lukion aineenopettajilla riittävästi tietoa ryhmäosaamisesta ja sen kehittymisen ohjaamisesta, mahdollisuuksia täydentää osaamistaan ja missä määrin oppikirjat voisivat tehdä ryhmäosaamisen asemaa näkyvämmäksi.

\section{Lopuksi}

Tämä tutkimus toi esiin tärkeän äänen, lukiolaisen äänen. Nykykoulun lähtökohta on oppijakeskeisyydessä, ja yhä enemmän kiinnitetään huomiota siihen, millä tavoin opiskelu ja oppiminen olisi tuloksellisempaa. Jotta oppijakeskeisyys ei jäisi vain ylevien tavoitelauseiden tasolle, opiskelijaa itseään on kuunneltava. Tämä tutkimus pyrki osaltaan toteuttamaan sitä. Tulosten hyödynnettävyys sijoittuu ensisijaisesti käytännön opetustyöhön. Sen tuloksia voikin hyödyntää käytännössä opetusmenetelmiä ja työtapoja valitessa sekä oppikirjojen kirjoitustyössä.

Yhteenvetona totean, että koulumaailman tulee pysyä ryhmäosaamisen kehitystyössä kiinteästi mukana ja miettiä ratkaisuja ja tapoja vahvistaa lukiolaisen osaamista myös tällä tavoin. Lukiolaisten ryhmäosaamiseen on tärkeää kiinnittää vahvemmin tulevaisuudessakin huomiota. Sen kehittymistä ei turvaa oletus tai toive vaan siihen on keskityttävä määrätietoisesti. Se on koko lukion asia, oppiaineiden yhteinen tehtävä - ei yksinomaan äidinkielen ja kirjallisuuden. Ryhmäosaaminen kuuluu kaikille.

TITLE AND KEYWORDS IN ENGLISH:

Group communication competence in upper secondary school belongs to everyone

KEYWORDS: communication education, group communication competence, textbook, upper secondary school 